\title{
TEMPORARY GENERALIZED OEDEMA OF OBSCURE ORIGIN
}

\author{
BY \\ R. S. ILLINGWORTH and E. FINCH \\ From the Children's Hospital Unit, the United Sheffield Hospitals
}

(RECEIVED FOR PUBLICATION MAY 20, 1954)

Very few papers have been written about temporary generalized oedema of unknown origin. When one has excluded such obvious causes of temporary oedema as starvation, nephritis, hepatitis, diarrhoea, heart failure, burns, chronic suppuration, excessive hydration, sodium retention due to drugs, or even drug allergy, there remains a group of cases in which oedema develops without apparent cause and disappears with equally little apparent reason.

Some writers have suggested that acute nephritis may occur without albuminuria. Keefer (1939) described a 16-year-old girl who presented with impetigo and generalized oedema with pleural effusions of five days' duration. The blood pressure was raised $(150 / 105 \mathrm{~mm}$. $\mathrm{Hg})$, but the serum proteins were not reduced (total $5.94 \mathrm{~g}$. per 100 ml., albumin $3 \cdot 2$ g.). The renal function tests were normal. All oedema disappeared in 14 days. Keefer ascribed the oedema to increased capillary permeability or pressure. Brod (1949) described a 28-year-old man who developed hypertension and oedema without albuminuria. The serum proteins were not estimated. The patient made a complete recovery. Crofton and Truelove (1948) described a girl of 16 who developed oedema and hypertension without albuminuria but with normal plasma proteins. They reviewed the literature, giving several references to similar cases. Other references to this condition were given by Keefer (1939) and by Salvesen and Bøe (1937).

One of the cases of obscure oedema described by Binger and Keith (1937) may have fallen into this category, for her blood pressure was $140 / 90 \mathrm{~mm}$. $\mathrm{Hg}$ on admission, but it is not clear whether it remained at this figure. The patient was a 49-yearold woman who had oedema for just over three months. The only abnormality noted was hypoproteinaemia (total serum proteins $3 \cdot 6-4 \cdot 5 \mathrm{~g}$. per $100 \mathrm{ml}$., albumin 2.4-2.6 g.). She was discharged free from oedema, but there is no note of whether she was followed up.
Meyer-Bisch (1925) described four adults with generalized oedema who were said to lose their oedema promptly when rested in bed. Three of the four had lowered serum proteins. One had steatorrhoea. All had achlorhydria.

Heimann and Gross (1933) described a nine-week episode of cedema in a 49-year-old man, with normal urine and blood pressure. Serum proteins were not estimated and no further data were available.

Messinger (1946) described an episode of generalized oedema, lasting eight months, in a 27 -year-old woman with a previous history of thyrotoxicosis. At the onset of the oedema she gained $20 \mathrm{lb}$. in a month. The blood pressure, urine and erythrocyte sedimentation rate were normal. The serum proteins were reduced (total $4.7 \mathrm{~g}$. per $100 \mathrm{ml}$, albumin 2.9 g.). No nitrogen balance was performed. The glucose tolerance curve was slightly flat during the phase of oedema, returning to normal when the oedema disappeared. There was some eosinophilia (19\% of 11,600 leucocytes). A highprotein diet was without effect. The oedema disappeared a month after pregnancy began. Messinger suggested that the hypoproteinaemia might have been due to a disturbance of the anterior pituitary, but the evidence for this was very slender.

Hertzog and Faust (1950) described an episode of oedema in a baby, lasting from the age of 2 weeks to 20 weeks. The urine was normal. The total serum proteins were $1.92 \mathrm{~g}$. per $100 \mathrm{ml}$. (albumin 1.45 g., globulin 0.47 g.). The serum calcium level varied between 6.2 and $7 \cdot 8 \mathrm{mg}$. per $100 \mathrm{ml}$., with a serum phosphorus level of 3.8 to $4.8 \mathrm{mg}$. per $100 \mathrm{ml}$. Liver function tests were normal. The protein content of the oedema fluid was 306 mg. per $100 \mathrm{ml}$., and $75 \mathrm{~g}$. of concentrated sodiumfree human albumin raised the total serum proteins by only $0.9 \mathrm{~g}$. per $100 \mathrm{ml}$. A spontaneous diuresis occurred, the oedema disappeared and the serum proteins returned to normal $(6 \cdot 5 \mathrm{~g}$. per $100 \mathrm{ml}$.). 
The writers suggested that the hypoproteinaemia was due to a temporary abnormality in protein synthesis and catabolism.

Wyngaarden, Crawford, Chamberlin and Lever (1952) described a 10-week episode of generalized oedema in a $3 \frac{1}{2}$-year-old boy, developing two weeks after tonsillitis. The case was well investigated. The total serum proteins were $3 \cdot 14 \mathrm{~g}$. per $100 \mathrm{ml}$. (albumin 2.37 g., globulin 0.77 g. per $100 \mathrm{ml}$.). Electrophoretic analysis showed that there was a considerable decrease in gamma globulin, with a slight elevation of the alpha globulins. The erythrocyte sedimentation rate, urea clearance and bromsulphthalein excretion tests were normal. Recovery was uneventful, the total and fractional serum protein values returning to normal.

Below are case histories of two children who were under our care in the Children's Hospital, Sheffield.

\section{Case Reports}

Case 1. R.M., a boy, was admitted at the age of $7 \frac{1}{2}$ months with a history of oliguria of two weeks' duration, puffiness of the eyes for 19 days, and distension of the abdomen for seven days. There was no previous illness of note.

On examination there was marked generalized oedema with ascites (Fig. 1). The circumference of the abdomen

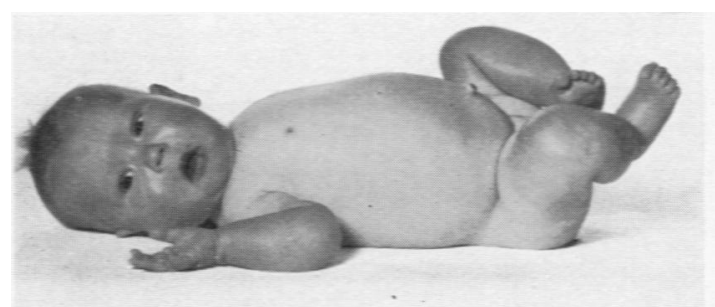

FiG. 1.-R.M., showing oedema, distension of abdomen, and everted umbilicus.

was 22 in. The heart and blood pressure were normal.

Three weeks after admission he had a spontaneous diuresis and the oedema disappeared, with a loss of $4 \mathrm{lb}$. in weight, the plasma proteins returning to normal. On follow-up for a period of almost five years there was no recurrence. The total duration of the oedema was therefore approximately five weeks.

INVESTIGATIONS. The methods used are the same as those described in the previous paper on page 507.

The urine was normal chemically and microscopically, with chlorides $260 \mathrm{mg}$. per $100 \mathrm{ml}$.

Haemoglobin was $13.3 \mathrm{~g}$. per $100 \mathrm{ml}$., red blood cells $5,100,000$ per c.mm.

The stools on repeated examination were normal macroscopically and microscopically.
Serum protein levels were as follows:

\begin{tabular}{|c|c|c|c|}
\hline \multirow{3}{*}{$\begin{array}{l}2 \text { days after admission } \ldots \\
6 \text { days after admission } \ldots \\
21 \text { days after admission and } 2 \\
\text { days after diuresis }\end{array}$} & Total & Albumin & Globulin \\
\hline & $\begin{array}{r}4 \cdot 7 \\
3 \cdot 8\end{array}$ & $\begin{array}{c}\text { per } 100 \mathrm{~m} \\
2.8 \\
1.8\end{array}$ & $\begin{array}{l}1.9 \\
2 \cdot 0\end{array}$ \\
\hline & $5 \cdot 4$ & $4 \cdot 1$ & $1 \cdot 3$ \\
\hline
\end{tabular}

Serum cholesterol level $260 \mathrm{mg}$. per $100 \mathrm{ml}$., serum alkaline phosphatase 9.7 King-Armstrong units, serum bilirubin $1.3 \mathrm{mg}$. per $100 \mathrm{ml}$., serum sodium $335 \mathrm{mg}$. per $100 \mathrm{ml}$. Blood urea was $35 \mathrm{mg}$. per $100 \mathrm{ml}$. A fat balance (10-day specimen) gave $88 \cdot 3^{\circ}$ 。 fat absorbed.

A nitrogen balance gave a total intake of $47.7 \mathrm{~g}$. nitrogen of which $15.5 \mathrm{~g}$. was excreted in the urine and $4.3 \mathrm{~g}$. in the stools, and $27.9 \mathrm{~g}$. was retained.

The Wassermann reaction was negative, as was the tuberculin reaction.

Case 2. M.H., a boy, was admitted to another hospital at the age of 3 years with a history of generalized oedema of insidious onset of one month's duration, following a cold and sore throat associated with vomiting. On examination at that hospital there was marked generalized oedema including the face, sacrum and lower limbs. The blood pressure was normal $(100 / 70 \mathrm{~mm}$. $\mathrm{Hg}$ ): the urine was normal and the erythrocyte sedimentation rate was $4 \mathrm{~mm}$. in an hour. The urea clearance test was normal. The oedema persisted, and he 8 was discharged home. He was first seen at this hospital six months after the onset. He had not been free from oedema during this period.

At this time he had slight generalized oedema, including the sacrum and lower limbs, and the eyes were puffy. The blood pressure was normal $(110 / 70 \mathrm{~mm}$. $\mathrm{Hg}$ ). The urine was normal chemically and microscopically, and the Addis count was normal. The erythrocyte sedimentation rate, blood urea and urea clearance tests were normal. The serum proteins were very low (3.4 g. per $100 \mathrm{ml}$.). He was discharged after a week with slight residual oedema, a diagnosis of idiopathic hypoproteinaemia being made. He was followed up as an out-patient, and mild oedema persisted.

He was re-admitted at the age of 4 years 1 month for further investigation. He weighed $40 \mathrm{lb}$, and had slight generalized oedema. Laboratory investigation showed hypoproteinaemia as before, with a positive nitrogen balance and a normal fat balance. Liver function tests were normal. The plasma showed decreased levels of tyrosine, tryptophane, arginine and valine. (It is interesting to note that the plasma of a similar patient, shown to the writers by Drs. Allibone and Prosser, showed the same decreased plasma amino-acid content, with, in addition, a decreased lysine content.)

A spontaneous diuresis occurred two weeks after admission, with loss of the oedema and a return of the serum protein to normal. He lost $3 \mathrm{lb}$. in weight. The total duration of oedema was approximately 14 months.

He has been followed up continually since his discharge, and there has been no recurrence. When last 


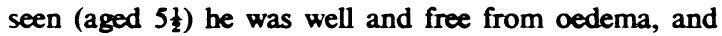
attending school regularly.

INVESTIGATIONS. At $3 \frac{1}{2}$ years of age the urine was normal chemically and microscopically with a specific gravity of 1,029 on repeated specimens. An Addis count gave: red cells 452,400 per 24 hours, white cells 638,400 per 24 hours, protein $26.6 \mathrm{mg}$. per 24 hours. Urea clearance were (1) $109 \%$ normal and (2) $121 \%$ normal.

Total serum proteins were $3 \cdot 4 \mathrm{~g}$. and $4 \cdot 3 \mathrm{~g}$. per $100 \mathrm{ml}$. (albumin $2 \cdot 1$ g., $3 \cdot 0$ g., globulin $1 \cdot 3$ g., 1.3 g.).

Blood urea was 23-24 mg. per $100 \mathrm{ml}$. The erythrocyte sedimentation rate was $7 \mathrm{~mm}$. per hour (micro.).

Three amino-acid chromatograms were taken by Dr. Bickel, the first at 3 years 7 months. It showed slightly increased excretion of cystine, alanine and glutamine, normal excretion of glycine, glutamic acid and histidine, traces of tyrosine, the leucines and valine. The total ninhydrin colour was 110 taurine units (normal up to 85). The pattern was not that of Lignac-Fanconi disease but resembled the pattern of renal amino-aciduria as in Wilson's disease. The second chromatogram at the age of 3 years and 8 months showed normal excretion of glycine, alanine, glutamine, and histidine, with traces of tyrosine, and a normal pattern. At 4 years 1 month the urine was normal, and an amino-acid chromatogram (Dr. Bickel) showed a normal pattern.

Wassermann and tuberculin reactions were negative. Haemoglobin was $12.6 \mathrm{~g}$. per $100 \mathrm{ml}$. and red cells were $4,400,000$ per c.mm. The erythrocyte sedimentation rate was $13 \mathrm{~mm}$. per hour (micro.), and the blood urea $21 \mathrm{mg}$. per $100 \mathrm{ml}$.

Total serum proteins were $3.0 \mathrm{~g}$. per $100 \mathrm{ml}$. (albumin 2.2 g., globulin 0.8 g.). Serum lipoids were $340 \mathrm{mg}$., serum cholesterol $94 \mathrm{mg}$., serum sodium $350 \mathrm{mg}$. and serum potassium $13 \mathrm{mg}$. per $100 \mathrm{ml}$. Thymol turbidity was $2 \cdot 8$ units.

On discharge two months later the serum proteins (total) were $5 \cdot 2 \mathrm{~g}$. per $100 \mathrm{ml}$. (albumin $3 \cdot 3 \mathrm{~g}$., globulin 1.9 g.). A nitrogen balance was positive, showing total intake of nitrogen $18.5 \mathrm{~g}$., output in urine $8.5 \mathrm{~g}$., output in stools $2 \cdot 7 \mathrm{~g}$., total $11 \cdot 2 \mathrm{~g}$., and retention $7 \cdot 3 \mathrm{~g}$. A fat balance gave $93 \cdot 5^{\circ}$ 。 retention of intake (three days). The total fat in faeces was $27.6 \%$ of dried faeces.

Plasma amino-acids (mg. per $100 \mathrm{ml}$.) were determined by Dr. Bickel as follows:

\begin{tabular}{|c|c|c|c|c|c|c|}
\hline \multicolumn{4}{|c|}{ Amino-acid } & \multirow{2}{*}{$\begin{array}{c}\text { Patients } \\
\text { M.H. } \\
0.66 \\
2 \cdot 41 \\
0 \cdot 79 \\
0.51\end{array}$} & \multicolumn{2}{|c|}{ Controls } \\
\hline $\begin{array}{l}\text { Phenylalanine } \\
\text { Valine } \\
\text { Tyrosine .. } \\
\text { Tryptophane } \\
\text { Lysine } \\
\text { Arginine .. }\end{array}$ & $\begin{array}{l}\cdots \\
\cdots \\
\cdots \\
\cdots \\
\cdots\end{array}$ & $\begin{array}{l}\cdots \\
\cdots \\
\cdots \\
\cdots \\
\cdots\end{array}$ & $\begin{array}{l}\cdots \\
\cdots \\
\cdots \\
\cdots \\
\cdots\end{array}$ & & $\begin{array}{c}A \\
0 \cdot 82 \\
2 \cdot 62 \\
1 \cdot 35 \\
1 \cdot 18 \\
2 \cdot 60 \\
2 \cdot 14\end{array}$ & $\begin{array}{c}\text { B } \\
0 \cdot 70 \\
3 \cdot 18 \\
1 \cdot 48 \\
1 \cdot 02 \\
2 \cdot 98 \\
2 \cdot 08\end{array}$ \\
\hline
\end{tabular}

There were decreased levels of tyrosine, tryptophane, arginine and valine.

At 4 years 5 months the total serum proteins were $5.9 \mathrm{~g}$. per $100 \mathrm{ml}$. (albumin $3.8 \mathrm{~g}$., globulin $2 \cdot 1 \mathrm{~g}$.), and at $5 \frac{1}{2}$ years total serum proteins $5.4 \mathrm{~g}$. per $100 \mathrm{ml}$. (albumin $3 \cdot 5 \mathrm{~g}$., globulin $1.9 \mathrm{~g}$.) An amino-acid chromatogram was still normal.

\section{Discussion}

The two children described presented a temporary oedema with hypoproteinaemia without any apparent reason. They did not fall into the group of cases described by Keefer (1939), Crofton and Truelove (1948), Brod (1949) and others as nephritis without albuminuria, for the blood pressure in our cases was normal and the serum proteins were reduced. We have only been able to find six references to cases which appeared to be similar (Meyer-Bisch, 1925; Heimann and Gross, 1933; Binger and Keith, 1937; Messinger, 1946; Hertzog and Faust, 1950; Wyngaarden, et al., 1952). Only the last two of these papers refer to children.

In both our cases the only significant finding was hypoproteinaemia with a particularly low serum albumin level. The nitrogen balance was positive in both. In one of the children there was a reduction of certain amino-acids in the serum; they were not estimated in the other child. There was no diarrhoea at any stage in either child, and no suggestion of a reduced protein intake or increased protein loss. The nature of the pathological process remains a matter of speculation. The observations are in accordance with the view that the primary disorder concerns the metabolism of the plasma proteins, in particular the albumin and globulin fractions. The fault may be either a reduced rate of production, or a failure of the mechanism controlling the concentration of the proteins in the plasma. It may be that the condition is essentially a mild and reversible form of the chronic oedema and hypoproteinaemia described in the previous paper.

\section{Summary}

Two cases of oedema with hypoproteinaemia are described, one lasting for five weeks and the other for 14 months. Recovery in both cases was spontaneous and complete.

It is suggested that the cause in both cases lay in a temporary disturbance of protein metabolism of unknown origin.

We wish to thank Professor H. A. Krebs, F.R.S., for his guidance in the study of these children and for his criticism of this paper. We also wish to thank Dr. H. Bickel for the amino-acid chromatograms.

RefERences

Binger, M. W. and Keith, N. M. (1937). J. Amer. med. Ass., 109, 1. Brod, J. (1949). Amer. J. Med., 7. 317.

Crofton, J. and Truelove, L. (1948). Lancet, 2. 54

Heimann, H. L. and Gross, I. (1933). S. Afr. med. J., 7. 259.

Heimann, H. L. and Gross, I. (1933). S. Afr. med. J., 7. 259.

Keefer, C. S. (1939). Tex. St. J. Med., 35, 457.

Messinger, M. J. (1946). Canad. med. Ass. J., 55, 381.

Meyer-Bisch, R. (1925). Klin. Wschr., 4, 588.

Salvesen, H. A. and Boe, J. (1937). Acta med. scand., 93, 228.

Wyngaarden, J. B., Crawford, J. D., Chamberlin, H. R. and Lever W. F. (1952). Pediatrics, 9. 729. 